NOTICE: This is the author's version of a work accepted for publication by Elsevier. Changes resulting from the publishing process, including peer review, editing, corrections, structural formatting and other quality control mechanisms, may not be reflected in this document. Changes may have been made to this work since it was submitted for publication. A definitive version was subsequently published in Review of Palaeobotany and Palynology 163: 26-34, doi:10.1016/j.revpalbo.2010.09.002

\title{
Anatomy and affinities of permineralized gymnospermous trunks with preserved bark from the Middle Triassic of Antarctica.
}

\author{
Anne-Laure DECOMBEIX ${ }^{\mathrm{a} *}$, Edith L. TAYLOR ${ }^{\mathrm{a}} \&$ Thomas N. TAYLOR ${ }^{\mathrm{a}}$ \\ ${ }^{a}$ Department of Ecology and Evolutionary Biology, and Natural History Museum and \\ Biodiversity Research Center, The University of Kansas, Lawrence, KS 66045-7534, U.S.A. \\ *Corresponding author. Tel.: +1 785864 4255; e-mail address: aldecomb @ ku.edu
}

\begin{abstract}
Permineralized gymnosperm axes with pycnoxylic wood from the Middle Triassic Fremouw Formation of the Central Transantarctic Mountains, Antarctica, are assigned to the corystosperms (seed ferns) and conifers. Both groups have been previously described from this formation based on juvenile stems with attached leaf bases and decorticated trunks. Here we describe large axes with preserved bark from the Fremouw Peak permineralized peat locality. The specimens are characterized by a small parenchymatous pith with clusters of sclereids, a thick cylinder $(>10 \mathrm{~cm}$ ) of pycnoxylic wood, and $1-2 \mathrm{~cm}$ of bark containing distinctive clusters of sclereids and a complex system of cortical vascular bundles. Comparison with axes previously described from the Middle Triassic of Antarctica shows that the new specimens are most similar to Kykloxylon, a corystosperm genus based on young stems bearing Dicroidium leaves, and with a portion of axis previously described as Rhexoxylon like. We suggest that both the new specimens and the Rhexoxylon-like axis represent proximal parts of a Dicroidium/Kykloxylon plant that possibly had a fluted trunk base, and we discuss the problem of delimiting features in corystosperm axes.
\end{abstract}

Key words: corystosperms; bark; stem anatomy; extraxylary tissues; Middle Triassic; Antarctica 
NOTICE: This is the author's version of a work accepted for publication by Elsevier. Changes resulting from the

publishing process, including peer review, editing, corrections, structural formatting and other quality control

mechanisms, may not be reflected in this document. Changes may have been made to this work since it was

submitted for publication. A definitive version was subsequently published in Review of Palaeobotany and Palynology 163: 26-34, doi:10.1016/j.revpalbo.2010.09.002

30

31

32

33

34

35

36

37

38

39

40

41

42

43

44

45

46

47

48

49

50

51

52

53

54

55

56

57

58

59

60

61

62

63

64

65

66

67

68

69

70

71

72

\section{Introduction}

Evidence of forest growth in Antarctica during the Triassic consists of in situ stumps and scattered woody axes, some preserved in permineralized peat. Paleogeographic reconstructions (e.g., Parrish, 1990) and tree-ring data (Taylor and Ryberg, 2007) indicate that these trees were growing in a temperate high-latitude environment characterized by a strongly seasonal light regime. Continued investigations of early Middle Triassic permineralized peat from Fremouw Peak in the Central Transantarctic Mountains have revealed that almost all major groups of Triassic gymnosperms were able to grow in these unusual conditions (see list in Taylor and Ryberg, 2007). Anatomically preserved stems include the cycad Antarcticycas, reconstructed as a small plant with a short upright or possibly subterranean stem (Smoot et al., 1985; Hermsen et al., 2009) and axes with a significant amount of pycnoxylic wood. Among the later, young stems or branches with attached leaf bases have been assigned to the conifers and seed ferns, specifically the podocarps (Notophytum, Meyer-Berthaud and Taylor, 1991) and corystosperms (Kykloxylon, Meyer-Berthaud et al., 1993). The affinities of large pieces of wood found at Fremouw Peak are, however, more problematic. In situ decorticated stumps of Jeffersonioxylon from contemporaneous or slightly younger deposits of nearby Gordon Valley were initially compared to the podocarps based on wood anatomy (Del Fueyo et al., 1995). The presence of leaf mats of the corystosperm morphogenus Dicroidium Gothan in the rocks which contained the stumps, however, led Cúneo and his collaborators (2003) to assign the wood to the corystosperms. In addition to these specimens, the outer part of a large axis with dissected secondary xylem from Fremouw Peak has been compared to Rhexoxylon Bancroft (Taylor, 1992). This genus, which is documented in Triassic-Lower Jurassic localities of South America and southern Africa (e.g., Walton, 1924; Archangelsky and Brett, 1961; Anderson and Anderson, 1983; Artabe et al., 1999; Bodnar, 2008), is traditionally assigned to the corystosperms based on co-occurrence with Dicroidium foliage in the Ischigualasto Formation of Argentina (Archangelsky, 1968).

In order to elucidate the affinities of the permineralized trees from the Fremouw Peak locality and to compare them in more detail to taxa found elsewhere in Gondwana, we searched for specimens providing additional anatomical information. In this report, we describe portions of trunks with well-preserved bark tissues. The presence of bark, which is rarely preserved in fossils, provides new information on the anatomy of these trees and allows for a more detailed comparison, especially with previously described juvenile axes from the Triassic of Antarctica. The term bark is used here, as defined by Esau (1965, p. 272), to include all the tissues located outside the secondary xylem, i.e., secondary phloem, primary phloem (if present), primary cortex (if present), and periderm. The epithet extraxylary is used here to designate structures located outside the secondary xylem but not part of the bark as defined above, i.e., vascular bundles.

\section{Material and methods}

The specimens were collected from a col on the north side of Fremouw Peak in the Beardmore Glacier area, Transantarctic Mountains, Antarctica (84¹7'41" S, 164² $\left.1^{\prime} 48^{\prime \prime} \mathrm{E}\right)$. They occur within the upper Fremouw Formation in permineralized peat, which is regarded as early Middle Triassic based on palynomorphs (Farabee et al., 1990). The specimens are silicified 
NOTICE: This is the author's version of a work accepted for publication by Elsevier. Changes resulting from the publishing process, including peer review, editing, corrections, structural formatting and other quality control mechanisms, may not be reflected in this document. Changes may have been made to this work since it was submitted for publication. A definitive version was subsequently published in Review of Palaeobotany and Palynology 163: 26-34, doi:10.1016/j.revpalbo.2010.09.002

and were studied using the cellulose acetate peel method (Galtier and Phillips, 1999) after the polished surface was etched for $2-3 \mathrm{~min}$ in $49 \%$ hydrofluoric acid. Some of the peels were scanned at 1200 dpi using a flatbed Epson Perfection V750 Pro scanner. Selected portions of peels were also mounted on microscope slides with Eukitt ${ }^{\circledR}$ medium for microscopic observation and photography. Cell and tissues measurements were made using Wright Cell Imaging Facility's ImageJ software (Rasband, 1997-2009). Unless specified in the text, averages correspond to a minimum of 50 measurements. Some images are composites of several photos in different focal planes created with the Stack Focuser plug-in of ImageJ; these are indicated in the figure explanations. Specimens are deposited in the Paleobotanical Collections, Natural History Museum and Biodiversity Institute, University of Kansas, under specimen numbers 10442, $10673,10808,11700,11773,15801,15830,15904$ and slide accession numbers 24012-24013 and 26538-26554.

\section{Description}

The specimens range from $2-15 \mathrm{~cm}$ long and $3-19 \mathrm{~cm}$ in diameter. They have a thick cylinder of pycnoxylic secondary xylem surrounded by $1-2 \mathrm{~cm}$ of bark containing distinctive clusters of thick-walled cells and vascular strands. All but one specimen consist of the external portion of large woody axes with their central part (pith and primary xylem) missing (Plate I, 1,2). The specimen preserved in peat block 10,808 represents a portion of a branching axis and provides some information on the anatomy of the pith.

\subsection{Secondary xylem (Plate I)}

In the largest specimen, the amount of preserved secondary xylem is up to $10 \mathrm{~cm}$ in thickness and is slightly wedge shaped in cross section (Plate I, 1,2). The tissue is composed exclusively of tracheids and narrow, parenchymatous rays (Plate I, 3). Numerous growth rings are present, each characterized by a small number of latewood tracheids. These show no significant increase in cell wall thickness compared to the earlywood tracheids, but are narrower in radial diameter (Plate I, 3). In some cases, the secondary xylem contains a so-called abnormal ring, characterized in transverse section by the presence of several discontinuous radial layers of parenchymatous tissue (Plate I, 4). These layers can occur within a typical growth ring, which indicates that they may have formed during the growing season.

One of the specimens $(15,830)$ also includes parenchymatous sectors that interrupt the secondary xylem cylinder (Plate I, 1,2,5). The anatomy of these regions is comparable to that of the inner bark (see \$3.2.) and consists of parenchymatous tissue containing scattered groups of thick-walled cells and small wedge-shaped vascular bundles with secondary growth (Plate I, 5). Most of the bundles have the same general orientation as the trunk, i.e., vertical, but a few follow a more oblique course. On both sides of the parenchymatous sectors, the secondary xylem of the trunk forms small wedges that extend in toward the parenchymatous interruption (Plate I, 5). In cross section, growth rings also appear curved inward on both sides of the parenchymatous sector (Plate I, 5).

Secondary xylem tracheids are square to polygonal in cross section and about $38 \mu \mathrm{m}$ in diameter (Plate I, 3). They have 1-3 rows of bordered pits on their radial walls (Plate I, 6) and up to 4 rows on the largest tracheids. Pits are circular when uniseriate, but hexagonal and crowded 
NOTICE: This is the author's version of a work accepted for publication by Elsevier. Changes resulting from the

publishing process, including peer review, editing, corrections, structural formatting and other quality control

mechanisms, may not be reflected in this document. Changes may have been made to this work since it was

submitted for publication. A definitive version was subsequently published in Review of Palaeobotany and Palynology

163: 26-34, doi:10.1016/j.revpalbo.2010.09.002

116

117

118

119

120

121

122

123

124

125

126

127

128

129

130

131

132

133

134

135

136

137

138

139

140

141

142

143

144

145

146

147

148

149

150

151

152

153

154

155

156

157

158

when bi- or multiseriate. They are about $13 \mu \mathrm{m}$ in diameter $(\mathrm{n}=25)$ and have a small $(2-5 \mu \mathrm{m})$ circular to elliptical aperture (Plate I, 6). Rays are uniseriate (Plate I, 7), rarely partly biseriate, and a few cells high $(<10)$. In tangential section, ray cells are rectangular in the center and rounded to pointed at the top and bottom of the rays; they measure $31 \times 52 \mu \mathrm{m}$. Cross-field pitting usually consists of several small, circular-to-oval pits (Plate I, 6, 8, arrowheads). Crossfield pits with horizontally elongated apertures are present in some cases (Plate I, 9).

\subsection{Bark (Plate II, III)}

The bark is characterized by the presence of conspicuous groups of thick-walled cells and a thin, sinuous periderm (Plate II, 1, Pe). The area immediately external to the secondary xylem, corresponding to the location of the vascular cambium and the youngest secondary phloem, is typically crushed or incompletely preserved (Plate II, 2, 3). The organization of old secondary phloem is clearly seen in some specimens (Plate II, 4). In transverse section, it is possible to recognize radially aligned thin-walled cells (Plate II, $4, \mathrm{t}$ ), most likely corresponding to the sieve cells and phloem parenchyma, as well as uniseriate parenchymatous rays (Plate II, 4, r) and conspicuous groups of polygonal thick-walled cells (Plate II, 2, 4, asterisk). The thin-walled cells have an average diameter of $46 \mu \mathrm{m}$ in transverse section and are elongated in longitudinal section (Plate II, 3).The thick-walled cells form ovoid clusters that average $200-250 \mu \mathrm{m}$ in diameter (range 50-400 $\mu \mathrm{m}$ ). Individual cells in the clusters are isodiametric (Plate II, 2-4) and characterized by polylamellate walls; they most likely represent sclereids (Parameswaran, 1980). The sclereids range from $20-120 \mu \mathrm{m}$ (average $60 \mu \mathrm{m}$ ) in diameter and have walls up to $27 \mu \mathrm{m}$ thick; primary pitting is visible in some cells. In areas where there are no extraxylary vascular bundles, clusters of sclereids occur in a somewhat regular arrangement and are visible extending outward to the periderm (Plate II, 5). In some specimens (e.g., 15,830; 11,700) there are no sclereid clusters in the inner bark, but they are present and regularly arranged in the outer bark.

The outermost region of the bark consists of a thin periderm that can show a very irregular course in cross section, most likely linked to the production of lateral organs (Plate I, 12; Plate II, 1, 6). The periderm has a relatively constant thickness of about $700 \mu \mathrm{m}$ and is composed of up to 40 layers of radially aligned, thin-walled cells that are rectangular in cross section and about 15 x $30 \mu \mathrm{m}$ (Plate II, 5, 6). In several specimens, areas with an anatomy similar to that of the bark and delimited by the same type of periderm are visible around the specimens (Plate II, 6). These could either indicate the production of several layers of periderm or the presence of the base of lateral organs that remained attached to the trunk. Because all the specimens represent only small sectors of trunks, it is not possible to determine accurately the anatomy and course of these putative lateral organs.

Vascular bundles with both secondary xylem and phloem occur in the bark and can vary in diameter (Plate I, 2; Plate II, 6, arrowhead; Plate III, 1); many are wedge shaped in transverse section (e.g., Plate II, 6, upper arrowhead). Secondary xylem is usually eccentric, i.e., much more developed on one side of the bundle (Plate II, 6), but in a few instances is equally developed on the two sides (Plate III, 1). The secondary xylem of these bundles is comparable in anatomy to that of the trunk. A lacuna or a zone of crushed opaque tissue outside the centrifugal xylem generally indicates the location of the secondary phloem (Plate III, 1). The orientation of the bundles in relation to that of the trunk is variable. For example, in specimen 15,830 most bundles 
NOTICE: This is the author's version of a work accepted for publication by Elsevier. Changes resulting from the

publishing process, including peer review, editing, corrections, structural formatting and other quality control

mechanisms, may not be reflected in this document. Changes may have been made to this work since it was

submitted for publication. A definitive version was subsequently published in Review of Palaeobotany and Palynology

163: 26-34, doi:10.1016/j.revpalbo.2010.09.002

159

160

161

162

163

164

165

166

167

168

169

170

171

172

173

174

175

176

177

178

179

180

181

182

183

184

185

186

187

188

189

190

191

192

193

194

195

196

197

198

199

200

201

have more extensive development of secondary tissues on the side located toward the center of the trunk, while in specimen 15,904 most bundles have a larger amount of secondary tissue on the side that is away from the center of the trunk. In a given transverse section, most bundles are oriented parallel to the vertical axis of the trunk, but a few appear in longitudinal section, running perpendicularly or obliquely.In some cases the bundles are branching within the bark.

\subsection{Axis center}

Specimen 10,888 represents a portion of a branching stem and is the only example where the center of an axis has been observed. The specimen has a wood and bark anatomy comparable to the others, but includes a portion of pith tissues about $255 \times 112 \mu \mathrm{m}$ wide in the center (Plate III, 2, Pi). The pith is composed of two types of cells, parenchyma cells that are poorly preserved or absent, and clusters of thick-walled sclereids 20-50 $\mu \mathrm{m}$ in diameter (Plate III, 2, asterisks). The secondary xylem forms a single solid cylinder around the pith, which indicates that its development was only centrifugal.

\section{Affinities}

Three groups of gymnosperms have been recognized in the permineralized peat from the Fremouw Peak formation: cycads, conifers, and corystosperms (seed ferns). In order to clarify the affinities of the new specimens, we provide here a comparison with stem morphogenera of these three groups previously described from this formation. A least two other gymnosperm groups have been reported in compression floras from the Triassic of Antarctica, the peltasperms and gingkoaleans (e.g., Escapa et al, 2010b). However, there is no information on the anatomy of peltasperm stems in general, and the specimens do not show any characters indicating ginkgoalean affinities such as heterogeneity of secondary xylem tracheid diameter (e.g., Scott et al., 1962). 4.1. Cycadophytes

The new specimens from the Fremouw Formation are characterized by a combination of a thick cylinder of pycnoxylic wood and parenchymatous bark with regularly arranged clusters of sclereids, as well as many vascular bundles that extend through the bark. The significant amount of parenchyma in the bark and the apparently complex arrangement of extraxylary bundles are somewhat similar to that of the cycadophytes. In both Cycadales and Bennettitales, however, stems typically exhibit only a narrow cylinder of secondary xylem compared to the width of the pith and cortex, a different configuration from that of the new Fremouw Peak axes. A few cycadophytes, however, produce a relatively large cylinder of wood; e.g., the extant cycad Dioon spinulosum can produce up to $10 \mathrm{~cm}$ of wood (Chamberlain, 1911). Antarcticycas is currently the most completely known fossil gymnosperm from the Fremouw Formation, with anatomically preserved stems, roots, leaves, cataphylls, and possible male cones (Smoot et al., 1985; Hermsen et al., 2009). All known Antarcticycas stems are small and only a few centimeters in diameter. Despite a somewhat similar appearance due to the width of the cortex and the sinuous periderm, Antarcticycas stems are easily distinguished from the new specimens by several features. These include the large parenchymatous pith, manoxylic secondary xylem, different anatomy of the secondary phloem, including the absence of clusters of sclereids, the presence of girdling leaf traces, and the presence of conspicuous mucilage canals in the pith and 
NOTICE: This is the author's version of a work accepted for publication by Elsevier. Changes resulting from the

publishing process, including peer review, editing, corrections, structural formatting and other quality control

mechanisms, may not be reflected in this document. Changes may have been made to this work since it was submitted for publication. A definitive version was subsequently published in Review of Palaeobotany and Palynology 163: 26-34, doi:10.1016/j.revpalbo.2010.09.002

cortex in Antarcticycas (Smoot et al., 1985). Since all or some of these characters are also found in other cycads, it is highly improbable that the new Fremouw specimens represent a cycad.

\subsection{Conifers and corystosperms}

Stem morphogenera of these two groups present numerous similarities and are thus considered here together. A discussion on the difficulty of distinguishing some fossil conifer and corystosperm stems is provided in the next section (\$5).

\subsubsection{Notophytum (conifer)}

Notophytum krauselii is represented in the Fremouw permineralized peat by roots, young stems, and large decorticated axes exceeding $20 \mathrm{~cm}$ in diameter. This plant is assigned to the conifers based on the anatomy of the secondary xylem and of the leaves attached to young stems (Meyer-Berthaud and Taylor, 1991); it has been suggested that the leaves correspond to the compression foliage taxon Heidiphyllum (Axsmith et al., 1998; Escapa et al., 2010a). The pith of Notophytum is exclusively composed of parenchyma cells, while the new specimens also have clusters of sclereids. Secondary xylem tracheids of Notophytum typically have a single row of circular pits on the radial walls and when biseriate, the pits are either opposite or alternate. Cross-field areas consistently show one to four, usually two large (7 x 12-24 $\mu \mathrm{m})$, oval-torectangular simple pits. This differs from the specimens described in this paper, which commonly have $2-3$ rows of radial pits and cross-field areas with numerous small, circular-toelongate pits. The secondary phloem of Notophytum is composed of multiseriate bands of sieve cells alternating with uni- to biseriate bands of parenchyma cells (Meyer-Berthaud and Taylor, 1991). Some of the older stems also have multiseriate bands of fibers, an organization that differs from the new specimens where the only recognizable thick-walled cells occur as clusters of sclereids. Finally, the periderm in Notophytum consists of large polyhedral cells with thickened walls (Meyer-Berthaud and Taylor, 1991).

\subsubsection{Jeffersonioxylon (corystosperm)}

Trunks of Jeffersonioxylon gordoniense from the Gordon Valley (Del Fueyo et al., 1995) are up to $60 \mathrm{~cm}$ in diameter. They occur rooted in shales containing mats of Dicroidium, a typical corystosperm leaf morphogenus (Cúneo et al., 2003). Jeffersonioxylon trunks are decorticated and variably compressed and, as a result, only their secondary xylem anatomy is known. Rays are mostly uniseriate and low, a condition found in all the non-cycad gymnosperms described to date from the Fremouw peat. Tracheid radial pitting in Jeffersonioxylon consists of one or two rows of pits in opposite or alternate arrangement. Cross-field pitting has been described as generally consisting of one or two circular to ovate pits, although some cross fields can contain up to four pits (Del Fueyo et al., 1995, fig. 15). Since the number of pits in a given cross field can depend on the diameter of the tracheid, the exact number is perhaps not a useful systematic character. Nevertheless cross-field pits of Jeffersonioxylon are smaller than the ones observed in the new specimens, which are only 3-5 $\mu \mathrm{m}$ in diameter. The limited number of characters available for comparison between Jeffersonioxylon and the new specimens prevents further assessment. 
NOTICE: This is the author's version of a work accepted for publication by Elsevier. Changes resulting from the

publishing process, including peer review, editing, corrections, structural formatting and other quality control

mechanisms, may not be reflected in this document. Changes may have been made to this work since it was

submitted for publication. A definitive version was subsequently published in Review of Palaeobotany and Palynology

163: 26-34, doi:10.1016/j.revpalbo.2010.09.002

\subsubsection{Kykloxylon (corystosperm)}

Young stems of Kykloxylon fremouwensis are assigned to the corystosperms based on the mode of production of leaf traces in the stems and anatomy of the leaves; leaves are those of Dicroidium fremouwensis from the same locality (Pigg, 1990; Meyer-Berthaud et al., 1992, 1993). Kykloxylon stems possess a parenchymatous pith containing secretory cavities and sclerotic nests comparable to the clusters of sclereids observed in the new trunks. The secondary xylem of Kykloxylon is characterized by tracheids with 1-3 rows of opposite-to-alternate pits on their radial walls, a configuration which is also similar to the new trunks with preserved bark. Kykloxylon has 3-9 pits in the cross fields; pits are oval to elongate and range from 7 x $10 \mu \mathrm{m}$ to $10 \times 25 \mu \mathrm{m}$, an arrangement and size comparable to that observed in the wood of the new trunks. The secondary phloem of Kykloxylon contains sieve cells and uniseriate parenchymatous rays (Meyer-Berthaud et al., 1993). There are conspicuous sclerotic nests in the pith, and sclereid clusters in the cortex and leaf bases of Kykloxylon that are similar in size and structure to those in the stems described here. Another similarity can be seen in the periderm of Kykloxylon, which consists of numerous radial rows of rectangular thin-walled cells. Thus, Kykloxylon appears to be the taxon that most closely resembles the new specimens. One distinct difference is the absence of secretory cavities which are typically found in several corystosperms organs from the Fremouw permineralized peat deposit, including Kykloxylon stems and leaf bases (MeyerBerthaud et al., 1993), Dicroidium fremouwensis foliage (Pigg, 1990), Pteruchus fremouwensis pollen organs (Yao et al., 1995) and Umkomasia resinosa cupulate organs (Klavins et al., 2002). It is possible that the secretory cavities are a feature of young organs, i.e. short shoots, leaves and reproductive organs. For example, juvenile shoots and twigs of the extant silver birch (Betula pendula) have resinous glands that are replaced by bark cells at the end of the growing season (Lapinjoki et al., 1991). Since several types of compressed Dicroidium foliage are recognized in Antarctica (e.g., Boucher et al., 1993; Escapa et al., 2010b), an alternative hypothesis is that there were several slightly different stems that bore this foliage morphotaxon.

\subsubsection{Rhexoxylon-like specimen of Taylor (1992) (?corystosperm)}

While Rhexoxylon is known from Africa and well documented in South America, only a fragmentary specimen from Antarctica has been compared to this genus (Taylor, 1992). The Antarctic specimen consists of the outer portion of a large axis with pycnoxylic secondary xylem forming wedges separated by parenchymatous tissue. The secondary xylem has cross-field areas with 2-6 small simple pits about $7 \mu \mathrm{m}$ wide. The lack of data on the primary tissues prevented a more detailed comparison of the specimen with Rhexoxylon, a genus characterized by medullary vascular bundles and centripetal secondary growth (e.g., Archangelsky and Brett, 1961). The extraxylary tissues in the Rhexoxylon-like axis from Antarctica include a zone more than $1 \mathrm{~cm}$ thick composed of parenchymatous ground tissue containing vascular strands (Plate III, 3). In cross section, the specimen has a layer of periderm (370-860 $\mu \mathrm{m}$ wide) that follows a sinuous path and is composed of thin-walled cells. Poorly preserved areas delimited by the same type of periderm are present in the outer part of the specimen and may represent the base of lateral organs. Although clusters of sclereids were not observed in the inner part of the bark, they are present in at least one of these external zones (Plate III, 3). 
NOTICE: This is the author's version of a work accepted for publication by Elsevier. Changes resulting from the

publishing process, including peer review, editing, corrections, structural formatting and other quality control

mechanisms, may not be reflected in this document. Changes may have been made to this work since it was

submitted for publication. A definitive version was subsequently published in Review of Palaeobotany and Palynology

163: 26-34, doi:10.1016/j.revpalbo.2010.09.002

The new specimens from Fremouw Peak share numerous characters with this Rhexoxylon-like axis, including the anatomy of the secondary xylem and extraxylary tissues, and the presence of parenchymatous sectors in the wood with anatomy comparable to that of the bark. To date no axis with a typical Rhexoxylon stele (i.e., containing medullary bundles and both centrifugal and centripetal secondary growth) has been found in the Triassic permineralized peat from Antarctica. A small number of gymnosperm axes from Fremouw Peak show slight development of centripetal secondary xylem (A.-L.D, personal observation); however, they lack perimedullary bundles and clearly differ from Rhexoxylon and from the new specimens, including in their bark anatomy. Currently, the most parsimonious hypothesis is that both the Rhexoxylon-like specimen of Taylor (1992) and the new specimens described in this paper represent the same arborescent taxon with corystosperm affinities. This plant type is characterized by trunks with a woody cylinder that may be dissected in its outer part but is more similar to Kykloxylon than to Rhexoxylon in stelar organization. It is possible that the Rhexoxylon-like specimen from Fremouw Peak represents growth after some type of wounding or part of a trunk with a fluted base. Fluted trunks are formed by the unequal production of secondary xylem around the circumference of the axis caused by a local reduction or absence of cambial activity (Schweingruber, 2007, p. 22-25). This phenomenon is well documented in extant trees such as the dawn redwood (Metasequoia glyptostroboides), and has also been reported in some fossil conifers (e.g., Falcon-Lang et al., 2004, p. 55). The unequal cambial activity has been linked to mechanical and physiological constraints (e.g., Day, 1964), although a genetic component is apparently present in at least some species, such as the common lime (Tilia $\mathrm{x}$ vulgaris, Pigott, 1992). The hypothesis that the so-called Rhexoxylon-like specimen from Antarctica represents part of a wounded or fluted trunk would explain its co-occurrence with axes that share numerous anatomical characters but in which the wood cylinder is complete or less dissected. In the case of a fluted trunk, these axes would represent higher portions of the trunk and branches; alternatively they could indicate the existence of a variation in trunk development within the same morphotaxon.

\subsection{Other corystosperm stems with preserved bark}

Bark tissues have been described in detail in only a few corystosperms. The presence of a thick cortex containing vascular strands as well as sclerotic nests and/or secretory cells has been documented in several species of Rhexoxylon. In R. africanum from southern Africa (Bancroft, 1913; Archangelsky and Brett, 1961), the cortex is over $1 \mathrm{~cm}$ thick and contains sclerotic nests and vascular strands. Rhexoxylon piatnitzkyi occurs in the Upper Triassic (Carnian) Ischigualasto Formation of Argentina and possesses a cortex containing vascular strands and "cysts," the latter term designating parenchyma cells with dark contents (Archangelsky and Brett, 1961). Specimens of $R$. cortaderitaense are known from the Middle Triassic Cortaderita Formation of San Juan Province, Argentina. These stems have a well-preserved cortex that is $1-3 \mathrm{~cm}$ wide and composed of parenchyma containing idioblasts, probable sclerotic nests, and regularly arranged structures described as vascular strands (Bodnar, 2008). Rhexoxylon brunoi (Upper Triassic Los Colorados Formation, Argentina) is described as including a rhytidome-like cork layer up to 2 $\mathrm{cm}$ thick that contains quadrangular or rectangular suberized cells (Artabe et al., 1999), but no detailed illustration of this tissue was provided. As far as we are aware, there is no detailed 
NOTICE: This is the author's version of a work accepted for publication by Elsevier. Changes resulting from the

publishing process, including peer review, editing, corrections, structural formatting and other quality control

mechanisms, may not be reflected in this document. Changes may have been made to this work since it was

submitted for publication. A definitive version was subsequently published in Review of Palaeobotany and Palynology

163: 26-34, doi:10.1016/j.revpalbo.2010.09.002

330

331

332

333

334

335

336

337

338

339

340

341

342

343

344

345

346

347

348

349

350

351

352

353

354

355

356

357

358

359

360

361

362

363

364

365

366

367

368

369

370

371

description of the cortex available for other corystosperm axes (e.g., Elchaxylon, Tranquiloxylon, Cuneumxylon).

\section{Distinguishing corystosperm and conifer stems}

Conifers and corystosperms co-occur in numerous Triassic localities throughout Gondwana. Both groups include large trunks with well-developed pycnoxylic wood, so distinguishing them solely based on the anatomy of decorticated axes can be problematic. Indeed, similar features of the primary and secondary vascular system can be found in Triassic conifer and corystosperm stems, and there are examples of taxa initially described as conifers that have been reassigned to the corystosperms, e.g., $R$. cortaderitaense (Bodnar, 2008), which was previously assigned to Protophyllocladoxylon Kräusel. Rhexoxylon Bancroft clearly differs from contemporaneous conifers by its mesarch primary xylem maturation, complex system of perimedullary bundles, and development of centripetal and centrifugal secondary xylem and phloem (e.g., Walton, 1924; Archangelsky and Brett, 1961). Other genera more recently included in the corystosperms, however, have endarch primary xylem maturation and lack perimedullary bundles, e.g., young stems of Kykloxylon from Antarctica (Meyer-Berthaud et al., 1993) and late Middle Triassic Cuneumxylon trunks from the Paramillo Formation of Argentina (Artabe and Brea, 2003). As far as wood anatomy is concerned, stems currently assigned to the corystosperms possess secondary xylem with uniseriate rays and 1-3 rows of pits on the radial wall of tracheids, a configuration that also occurs in numerous taxa of Mesozoic conifers (e.g., Philippe and Bamford, 2008). Araucarioid and podocarpoid types of cross-field pitting have been described in taxa assigned to both groups. Rhexoxylon africanum has only one large pit in each cross field, but there is significant variation in both shape and number of cross-field pits within the genus Rhexoxylon (see Artabe and Brea, 2003, table 2).

A component of the problem of distinguishing corystosperm and conifer stems comes from the differential weight given by authors to various sets of anatomical characters. Corystosperms have been defined based on foliage and reproductive structures (family Corystospermaceae of Thomas, 1933; Corystospermales of Taylor et al., 2009). Corystosperm stems can thus be defined as stems bearing Dicroidium foliage, Pteruchus pollen organs, or Umkomasia ovulate structures. However, the different organs are typically found detached in the fossil record or are attached but preserved in compression, so the stem anatomy remains unknown (Axsmith et al., 2000; Anderson et al., 2008). The assignment to the corystosperms of anatomically preserved axes from Antarctica is based on association with Dicroidium leaf mats in the case of Jeffersonioxylon trunks (Cúneo et al., 2003). In the case of Kykloxylon, the evidence is much stronger, based on the presence of attached leaf bases with an anatomy similar to Dicroidium leaves, especially the presence of diagnostic secretory cells in the cortex of stems, leaf bases, and leaves (Pigg, 1990; Meyer-Berthaud et al., 1992, 1993). The assignment of Rhexoxylon stems to the corystosperms is based on their repeated association with compressed Dicroidium leaves in the Ischigualasto Formation of Argentina (Archangelsky, 1968). Although Archangelsky and Brett (1961) described the presence of a complex leaf base in R. pianitzkyi, no clear anatomical connection between Rhexoxylon and Dicroidium has ever been conclusively demonstrated in silicified specimens. Consequently, the only stem attached to Dicroidium-like 
NOTICE: This is the author's version of a work accepted for publication by Elsevier. Changes resulting from the

publishing process, including peer review, editing, corrections, structural formatting and other quality control

mechanisms, may not be reflected in this document. Changes may have been made to this work since it was

submitted for publication. A definitive version was subsequently published in Review of Palaeobotany and Palynology

163: 26-34, doi:10.1016/j.revpalbo.2010.09.002

372

373

374

375

376

377

378

379

380

381

382

383

384

385

386

387

388

389

390

391

392

393

394

395

396

397

398

399

400

401

402

403

404

405

406

407

408

409

410

411

412

413

414

foliage with anatomy is Kykloxylon, and the similarities of the new trunks described in this paper to this genus are a good indication of their corystosperm affinities.

Artabe and Brea (2003) base their concept of corystosperm stems on the presence of anomalous secondary growth (see also Axsmith et al., 2007; Artabe and Brea, 2007 for a discussion of this concept), because Rhexoxylon, the first genus of stems assigned to the group, has a dissected cylinder with both centripetal and centrifugal secondary xylem present in each segment of the stele, as well as perimedullar bundles. Centripetal secondary xylem has also been described in Elchaxylon (Artabe and Zamuner, 2007) from the Upper Triassic of Mendoza province, Argentina, although in this taxon, the centrifugal secondary xylem is a continuous cylinder. Two other South American genera, Cuneumxylon (Artabe and Brea, 2003) and Tranquiloxylon (Herbst and Lutz, 1995), have been included in the corystosperms based on the existence of so-called anomalous secondary development. This includes unequal activity of the vascular cambium around the circumference of the stem, which produces a fluted axis, and the presence of supernumerary cambia producing included phloem. Both characters are present in Cuneumxylon, while Tranquiloxylon only shows unequal activity of the cambium. Artabe and Brea (2003) did not consider Kykloxylon in their synthesis on corystosperm stems because of its solid cylinder of wood. However, Kykloxylon was described from young stems (1-5 years old) and in Cuneumxylon, for example, the first supernumerary cambium occurs after the formation of $6 \mathrm{~cm}$ of wood (Artabe and Brea, 2003). If peculiarities of secondary growth that might occur later in development are not considered, it might be hypothesized that Tranquiloxylon and Cuneumxylon have more in common with Kykloxylon and the new Antarctic specimens than with Rhexoxylon. In particular, these three taxa all lack perimedullary bundles and any form of centripetal secondary growth, as well as having primary xylem maturation that is endarch instead of mesarch. In addition, both Cuneumxylon and the Antarctic specimens have secondary xylem that displays several cross-field pits instead of 1-3 large pits as in Rhexoxylon. If placed on the two conjectural corystosperm phylogenetic trees of Bodnar (2008), which are mostly based on secondary growth characters, the new Antarctic specimens would be grouped either with Tranquiloxylon and Cuneumxylon (Bodnar, 2008, fig. 10A) or with Kykloxylon in the group with "normal cylinder axes" (Bodnar, 2008, fig. 10B). Whether the so-called "non-anomalous" secondary growth of the new axes, Kykloxylon, Tranquiloxylon, and Cuneumxylon results from a loss of characters present in Rhexoxylon (as suggested by Bodnar) or is in fact primitive remains to be tested.

\section{Conclusion}

Two types of Dicroidium plants have been proposed: (1) a Dicroidium/Rhexoxylon plant with a tree fern-like habit (Petriella, 1978), based on the association of $D$. zuberi foliage and $R$. piatnitzkyi stems in the Ischigualasto Formation of Argentina (Archangelsky, 1968), and (2) a Dicroidium/Kykloxylon plant in Antarctica with a solid cylinder of pycnoxylic wood and foliage that was probably seasonally deciduous, i.e., a more conifer-like habit (Meyer-Berthaud et al., 1993, Taylor et al., 2006). The presence of large axes in the permineralized peat from Fremouw Peak that share numerous anatomical characters with Kykloxylon supports the idea that this genus represents the distal part of an arborescent plant that bore Dicroidium leaves and had a stelar organization different from Rhexoxylon. In this context, it is interesting to note that 
NOTICE: This is the author's version of a work accepted for publication by Elsevier. Changes resulting from the publishing process, including peer review, editing, corrections, structural formatting and other quality control mechanisms, may not be reflected in this document. Changes may have been made to this work since it was submitted for publication. A definitive version was subsequently published in Review of Palaeobotany and Palynology 163: 26-34, doi:10.1016/j.revpalbo.2010.09.002

\section{Acknowledgements}

The authors thank Josefina Bodnar (Museo de La Plata, Argentina) for sharing photos of Rhexoxylon cortaderitaense and Rudolph Serbet (University of Kansas) for help with the specimens. Two anonymous reviewers are also thanked for their detailed comments and suggestions on an earlier version of this paper. This work was supported by funds from the National Science Foundation (grant OPP-0635477 to ELT and TNT).

\section{References}

Anderson, J.M., Anderson, H.M., 1983. Palaeoflora of Southern Africa: Molteno Formation (Triassic) - Volume 1, Part 1. Introduction, Part 2. Dicroidium. A.A. Balkema, Rotterdam Anderson, H.M., Holmes, W.B.K., Fitness, L.A., 2008. Stems with attached Dicroidium leaves from the Ipswich Coal Measures, Queensland, Australia. Memoirs of the Queensland Museum 52, 1-12.

Archangelsky, S., 1968. Studies on Triassic fossil plants from Argentina. IV. The leaf genus Dicroidium and its possible relation to Rhexoxylon stems. Palaeontology 11, 500-512. Archangelsky, S., Brett, D.W., 1961. Studies on Triassic fossil plants from Argentina. I. Rhexoxylon from the Ischigualasto Formation. Philosophical Transactions of the Royal Society of London B 244, 1-19.

Artabe, A.E., Brea, M., 2003. A new approach to Corystospermales based on Triassic permineralized stems from Argentina. Alcheringa 27, 209-229.

Artabe, A.E., Brea, M., 2007. Réplica al trabajo de Axsmith et al. (2007) publicado en Ameghiniana 44: 223-230: The 'new approach to Corystospermales' and the Antarctic fossil record: a critique. Ameghiniana 44, $739-746$ [in Spanish with English abstract].

Artabe, A.E., Zamuner, A.B., 2007. Elchaxylon, a new corystosperm based on permineralized stems from the Late Triassic of Argentina. Alcheringa 31, 85-96.

Artabe, A.E., Brea M., Zamuner, A.B., 1999. Rhexoxylon brunoi Artabe, Brea et Zamuner, sp. nov., a new Triassic corystosperm from the Paramillo de Uspallata, Mendoza, Argentina. Review of Palaeobotany and Palynology 105, 63-74.

Axsmith, B.J., Taylor, T.N., Taylor, E.L., 1998. Anatomically preserved leaves of the conifer Notophytum krauselii (Podocarpaceae) from the Triassic of Antarctica. American Journal of Botany 85 704-713.

Axsmith, B.J., Taylor, E.L., Taylor, T.N., Cúneo, N.R., 2000. New perspectives on the Mesozoic seed fern order Corystospermales based on attached organs from the Triassic of Antarctica. American Journal of Botany 87, 757-768. 
NOTICE: This is the author's version of a work accepted for publication by Elsevier. Changes resulting from the

publishing process, including peer review, editing, corrections, structural formatting and other quality control

mechanisms, may not be reflected in this document. Changes may have been made to this work since it was

submitted for publication. A definitive version was subsequently published in Review of Palaeobotany and Palynology 163: 26-34, doi:10.1016/j.revpalbo.2010.09.002

Axsmith, B.J., Taylor, E.L., Taylor, T.N., 2007. The "new approach to Corystospermales" and the Antarctic fossil record: a critique. Ameghiniana 44, 223-230.

Bancroft, N., 1913. Rhexoxylon africanum, a new medullosean stem. Transactions of the Linnean Society of London 8, 87-103.

Bodnar, J., 2008. Rhexoxylon cortaderitaense (Menéndez) comb. nov., a species of permineralized stems newly assigned to the Corystospermaceae, from the Triassic of Argentina. Alcheringa 32, 171-190.

Boucher L.D., Taylor E.L., Taylor T.N., 1993. Dicroidium from the Triassic of Antarctica. New Mexico Museum of Natural History and Science Bulletin 3, 39-46.

Chamberlain, C.J., 1911. The adult cycad trunk. Botanical Gazette 52, 81-104.

Cúneo, N.R., Taylor, E.L., Taylor, T.N., Krings, M., 2003. In situ fossil forest from the upper Fremouw Formation (Triassic) of Antarctica: paleoenvironmental setting and paleoclimate analysis. Palaeogeography, Palaeoclimatology, Palaeoecology 197, 239261.

Day, W.R., 1964. The development of flutes or hollows on main stems of trees and its relation to bark splitting and strip necrosis. Forestry 37, 145-160.

Del Fueyo, G., Taylor, E.L., Taylor, T.N., Cúneo, N.R., 1995. Triassic wood from the Gordon Valley, central Transantarctic Mountains, Antarctica. IAWA Journal 16, 111-126.

Esau, K., 1965. Plant anatomy. 2nd Edition. J. Wiley and sons, New York. 767 pp.

Escapa, I.H., Decombeix, A.-L., Taylor, E.L., Taylor, T.N., 2010a. Evolution and relationships of the conifer seed cone Telemachus: evidence from the Triassic of Antarctica. International Journal of Plant Sciences 171, 560-573.

Escapa, I.H., Taylor, E.L., Cúneo, R., Bomfleur, B., Bergene, J., Serbet, R., Taylor, T.N., 2010b, submitted. Triassic floras of Antarctica: Plant diversity and distribution in high paleolatitude communities. PALAIOS submitted.

Falcon-Lang, H.J., MacRae, R.A. and Csank, A.Z., 2004. Palaeoecology of Late Cretaceous polar vegetation preserved in the Hansen Point Volcanics, NW Ellesmere Island, Canada. Palaeogeography, Palaeoclimatology, Palaeoecology 212, 45-64.

Farabee, M.J., Taylor, E.L., Taylor, T.N., 1990. Correlation of Permian and Triassic palynomorph assemblages from the central Transantarctic Mountains, Antarctica. Review of Palaeobotany and Palynology 65, 257-265.

Galtier, J., Phillips, T.L., 1999. The acetate peel technique. In: Jones, T.P., Rowe, N.P. (eds.), Fossil Plants and Spores: Modern Techniques. The Geological Society, London, UK, pp. 67-70.

Hermsen, E.J., Taylor, E.L., Taylor, T.N., 2009. Morphology and ecology of the Antarcticycas plant. Review of Palaeobotany and Palynology 153, 108-123.

Herbst, R., Lutz, A., 1995. Tranquiloxylon petriellai nov. gen. et sp. (Pteridospermale) from the Upper Triassic Laguna Colorada Formation, Santa Cruz Province, Argentina. Ameghiniana 32, 231-236.

Klavins, S.D., Taylor, T.N., Taylor, E.L., 2002. Anatomy of Umkomasia (Corystospermales) from the Triassic of Antarctica. American Journal of Botany 89, 664-676.

Lapinjoki, S.P., Elo, H.A., Taipale, H.T., 1991. Development and structure of resin glands on tissues of Betula pendula Roth. during growth. New Phytologist 117, 219-223. 
NOTICE: This is the author's version of a work accepted for publication by Elsevier. Changes resulting from the

publishing process, including peer review, editing, corrections, structural formatting and other quality control

mechanisms, may not be reflected in this document. Changes may have been made to this work since it was

submitted for publication. A definitive version was subsequently published in Review of Palaeobotany and Palynology 163: 26-34, doi:10.1016/j.revpalbo.2010.09.002

500

501

502

503

504

505

506

507

508

509

510

511

512

513

514

515

516

517

518

519

520

521

522

523

524

525

526

527

528

529

530

531

532

533

534

535

536

537

538

539

540

541

542

Meyer-Berthaud, B., Taylor, T.N., 1991. A probable conifer with podocarpacean affinities from the Triassic of Antarctica. Review of Palaeobotany and Palynology 67, 179-198.

Meyer-Berthaud, B., Taylor, E.L., Taylor, T.N., 1992. Reconstructing the Gondwana seed fern Dicroidium: Evidence from the Triassic of Antarctica. Géobios 25, 341-344.

Meyer-Berthaud, B., Taylor, T.N., Taylor, E.L., 1993. Petrified stems bearing Dicroidium leaves from the Triassic of Antarctica. Palaeontology 36, 337-356.

Parameswaran, N., 1980. Some remarks on the nomenclature of fibres, sclereids and fibresclereids in the secondary phloem of trees. IAWA Bulletin 1, 130-132.

Parrish, J.T., 1990. Gondwanan paleogeography and paleoclimatology. In: Taylor, T.N., Taylor, E.L. (eds.), Antarctic Paleobiology: Its Role in the Reconstruction of Gondwana. Springer-Verlag, New York, NY, pp. 15-26.

Petriella, B., 1978. La reconstrucción de Dicroidium (Pteridospermopsida, Corystospermaceae). Obra del Centenario del Museo de La Plata 5, 107-110.

Philippe, M., Bamford, M.K., 2008. A key to morphogenera used for Mesozoic conifer-like woods. Review of Palaeobotany and Palynology 148, 184-207.

Pigg, K.B., 1990. Anatomically preserved Dicroidium foliage from the central Transantarctic Mountains. Review of Palaeobotany and Palynology 66, 129-145.

Pigott, D., 1992. The clones of common lime (Tilia x vulgaris Hayne) planted in England during the seventeenth and eighteenth centuries. New Phytologist 121, 487-493.

Rasband, W.S., 1997-2009. ImageJ. U. S. National Institutes of Health, Bethesda, Maryland, USA, http://rsb.info.nih.gov/ij.

Scott, R.A., Barghoorn, E.S.,Prakash, U., 1962. Wood of Ginkgo in the Tertiary of Western North America. American Journal of Botany 49, 1095-1101.

Smoot, E.L., Taylor, T.N., Delevoryas, T., 1985. Structurally preserved fossil plants from Antarctica. I. Antarcticycas, gen. nov., a Triassic cycad stem from the Beardmore Glacier Area. American Journal of Botany 72, 1410-1423.

Taylor, E.L., 1992. The occurrence of a Rhexoxylon-like stem in Antarctica. Courier Forschungsinstitut Senckenberg 147, 183-189.

Taylor, E.L., Taylor, T.N., Kerp, H., Hermsen, E.J., 2006. Mesozoic seed ferns: Old paradigms, new discoveries. Journal of the Torrey Botanical Society 133, 62-82

Taylor, E.L., Ryberg, P.E., 2007. Tree growth at polar latitudes based on fossil tree ring analysis. Palaeogeography, Palaeoclimatology, Palaeoecology 255, 246-264.

Taylor, T.N., Taylor, E.L., Krings, M., 2009. Paleobotany: The Biology and Evolution of Fossil Plants, Second Edition. Academic Press, Burlington, MA, 1230 pp.

Thomas, H.H., 1933. On some pteridospermous plants from the Mesozoic rocks of South Africa. Philosophical Transactions of the Royal Society of London. Series B 222, 193-26.

Walton, J., 1924. On Rhexoxylon, Bancroft-A Triassic genus of plants exhibiting a liane-type of vascular organisation. Philosophical Transactions of the Royal Society of London Series B-Biological Sciences 212, 79-109.

Yao, X., Taylor, T.N., Taylor, E.L., 1995. The corystosperm pollen organ Pteruchus from the Triassic of Antarctica. American Journal of Botany 82, 535-546. 
NOTICE: This is the author's version of a work accepted for publication by Elsevier. Changes resulting from the publishing process, including peer review, editing, corrections, structural formatting and other quality control mechanisms, may not be reflected in this document. Changes may have been made to this work since it was submitted for publication. A definitive version was subsequently published in Review of Palaeobotany and Palynology 163: 26-34, doi:10.1016/j.revpalbo.2010.09.002

\section{Figure legends}

Plate I. Trunks with preserved bark from the Middle Triassic of Antarctica: general aspect (1-2) and secondary xylem anatomy (3-9). Center of the trunk is toward the bottom in all transverse sections. Legend: Pe: periderm, T: parenchymatous sectors in wood, X2: secondary xylem, *: cluster of sclereids.

1: Transverse section of specimen 15,830. Scanned peel 15,830 C \#1; scale bar $=2 \mathrm{~cm}$.

2: Line drawing of the specimen in Fig. 1 in transverse section showing secondary xylem (X2), extraxylary tissues (grey area) with cortical vascular bundles of various sizes (black) and periderm (Pe), and two parenchymatous sectors $(\mathrm{T})$ in the secondary xylem. Scanned peel 15,830 $\mathrm{C} \# 1$; scale bar $=2 \mathrm{~cm}$.

3: Transverse section through portions of two growth rings showing ring boundary. Note that latewood tracheids (arrowhead) show reduced radial diameter but similar wall thickness to earlywood tracheids. Slide 26538 (peel 15,830 A2bot \#3 $\alpha$ ); scale bar $=200 \mu \mathrm{m}$.

4: So-called abnormal growth ring in transverse section containing disorganized growth and parenchyma cells. Slide 26538 (peel 15,830 A2bot \#3 $\alpha$ ); scale bar $=250 \mu \mathrm{m}$; focused stack of three images.

5: Parenchymatous sector (T) partially dividing the woody cylinder as viewed in transverse section. Note the presence of clusters of sclereids $(*)$ and that the secondary xylem and the growth rings are curved inward on either side of the sector. Slide 26539 (peel 15,830 A2bot \#5); scale bar $=2.5 \mathrm{~mm}$.

6: Oblique radial section showing multiseriate pitting on the radial wall of tracheids and crossfield pitting (arrowheads). Slide 26542 (peel 15,830 A side); scale bar $=100 \mu \mathrm{m}$.

7: Low uniseriate rays and inter-tracheid pitting (arrowhead) in tangential section. Slide 26544 (peel 15,904 E \#1 $\beta$ ); scale bar $=100 \mu \mathrm{m}$.

8: Detail of cross field with several small circular pits (arrowheads) in radial section. Slide 26542 (peel 15,830 A side); scale bar $=25 \mu \mathrm{m}$.

9: Detail of cross field with elongated pits in radial section. Slide 26547 (peel 15,904 E \#2ß); scale $b a r=25 \mu \mathrm{m}$; focused stack of three images.

Plate II. Trunks with preserved bark from the Middle Triassic of Antarctica: bark anatomy. Center of the trunk is toward the bottom in all transverse sections. Legend: P2: old, probably non-functioning, secondary phloem, Pe: periderm, r: root, T: parenchymatous sectors in wood, $\mathrm{X} 2$ : secondary xylem, *: cluster of sclereids.

1: Transverse section of etched surface of specimen showing the secondary xylem, secondary phloem with conspicuous groups of thick-walled cells (darker spots), and periderm (Pe). Specimen 10,673 Btop; scale bar $=1 \mathrm{~cm}$. 2: Secondary xylem, cambial zone, and young phloem (double-headed arrow), and inner part of the old secondary phloem in transverse section; slide 26554 (peel 10,673 Btop \#2); scale bar = $200 \mu \mathrm{m}$.

3: Secondary xylem, cambial zone, and inner part of the old secondary phloem in oblique radial section. Note elongate cells in the secondary phloem (bottom center). Slide 26547 (peel 15,904 E $\# 2 \beta)$; scale bar $=200 \mu \mathrm{m}$. 
NOTICE: This is the author's version of a work accepted for publication by Elsevier. Changes resulting from the publishing process, including peer review, editing, corrections, structural formatting and other quality control mechanisms, may not be reflected in this document. Changes may have been made to this work since it was submitted for publication. A definitive version was subsequently published in Review of Palaeobotany and Palynology 163: 26-34, doi:10.1016/j.revpalbo.2010.09.002

586

587

588

589

590

591

592

593

594

595

596

597

598

599

600

601

602

603

604

605

606

607

608

609

610

611

612

613

4: Detail of inner part of old secondary phloem in transverse section showing thin-walled cells (r, sieve elements or parenchyma), a ray (r), and sclereids. Slide 2655426547 (peel 10,673 Btop \#2); scale bar $=100 \mu \mathrm{m}$.

5: Outer region of the bark in transverse section showing regularly arranged groups of sclereids within the outermost secondary phloem (thin-walled cells) and the inner part of the periderm $(\mathrm{Pe})$. Note that the expansion of the dark cells in this region mostly disrupts the radial arrangement of the cells. Slide 26554 (peel 10,673 Btop \#2); scale bar $=200 \mu \mathrm{m}$.

6: Outer region of a specimen in transverse section showing the sinuous course of the periderm (folded on itself at the bottom left), two large vascular bundles (arrowheads), and young roots (r) in the matrix outside the bark. Slide 26546 (peel 15,904 E \#2 $\alpha$ ); scale $=2.5 \mathrm{~mm}$.

Plate III. Trunks with preserved bark from the Middle Triassic of Antarctica (1-2) and specimen described as Rhexoxylon like (Taylor 1992) from the same locality (3). Center of the trunk is toward the bottom in all transverse sections. Legend: Pe: periderm, Pi: pith, T: parenchymatous sectors in wood, X2: secondary xylem, *: cluster of sclereids.

1: Detail of medium-sized cortical bundle in transverse section with secondary tissues developed on two sides. The possible remains of the crushed secondary phloem (brown material, lower right) are present outside the wider portion of secondary xylem. Slide 26549 (peel 11,700 B \#1); scale bar $=250 \mu \mathrm{m}$.

2: General view of pith (Pi) in branching axis in transverse/oblique section; note clusters of sclereids. Slide 26552 (peel 10,888 D \#1); scale bar $=1 \mathrm{~mm}$.

3: Outer part of the Rhexoxylon-like axis described by Taylor (1992) showing the wedge-shaped secondary xylem (X2) interrupted by a parenchymatous sector (T). The bark contains extraxylary vascular bundles (two are indicated by arrowheads), and a zone delimited by a periderm that might represent the base of a lateral organ. Note the clusters of sclereids in this zone. Scan of peel 11,314 D1 top \#1; scale bar $=500 \mu \mathrm{m}$. 
NOTICE: This is the author's version of a work accepted for publication by Elsevier. Changes resulting from the

publishing process, including peer review, editing, corrections, structural formatting and other quality control

mechanisms, may not be reflected in this document. Changes may have been made to this work since it was

submitted for publication. A definitive version was subsequently published in Review of Palaeobotany and Palynology 163: 26-34, doi:10.1016/j.revpalbo.2010.09.002
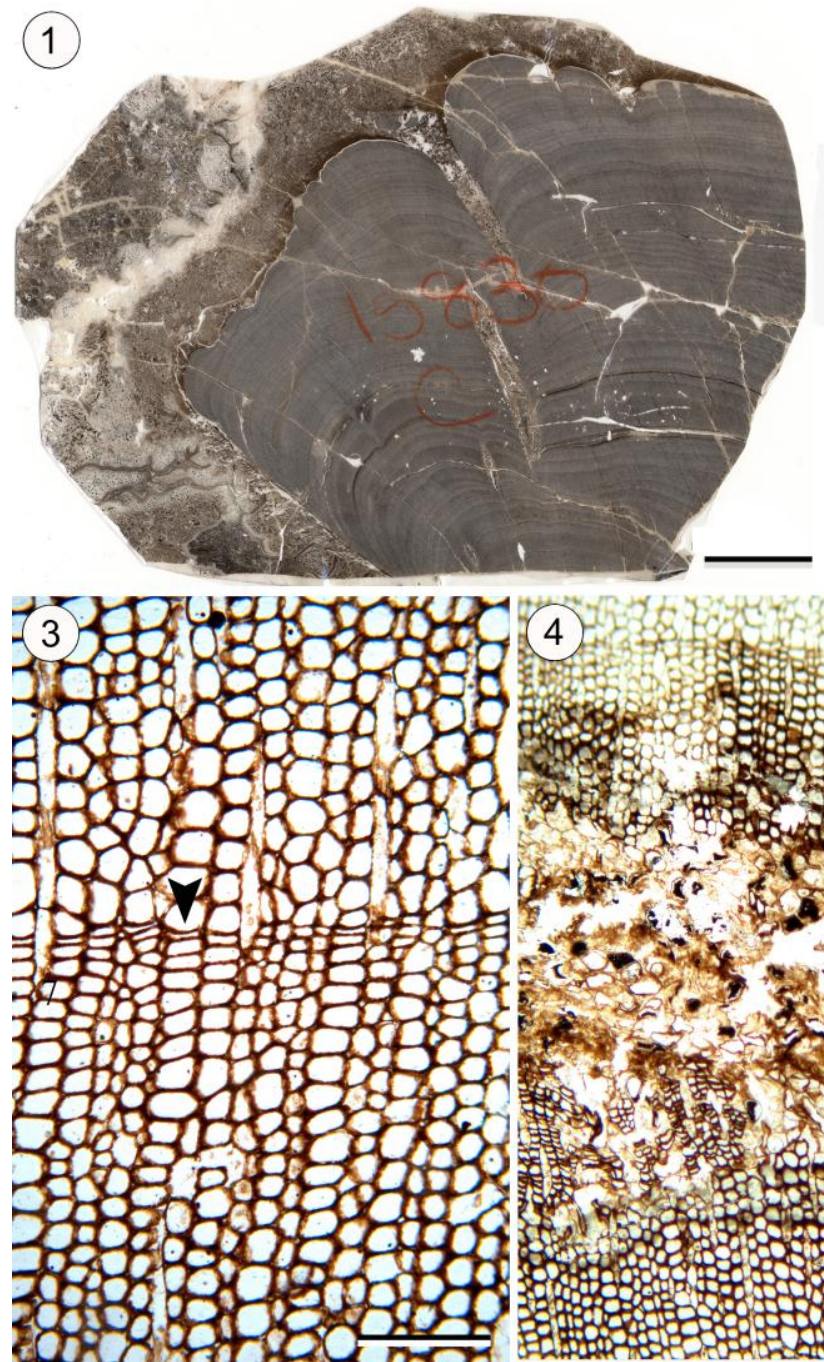
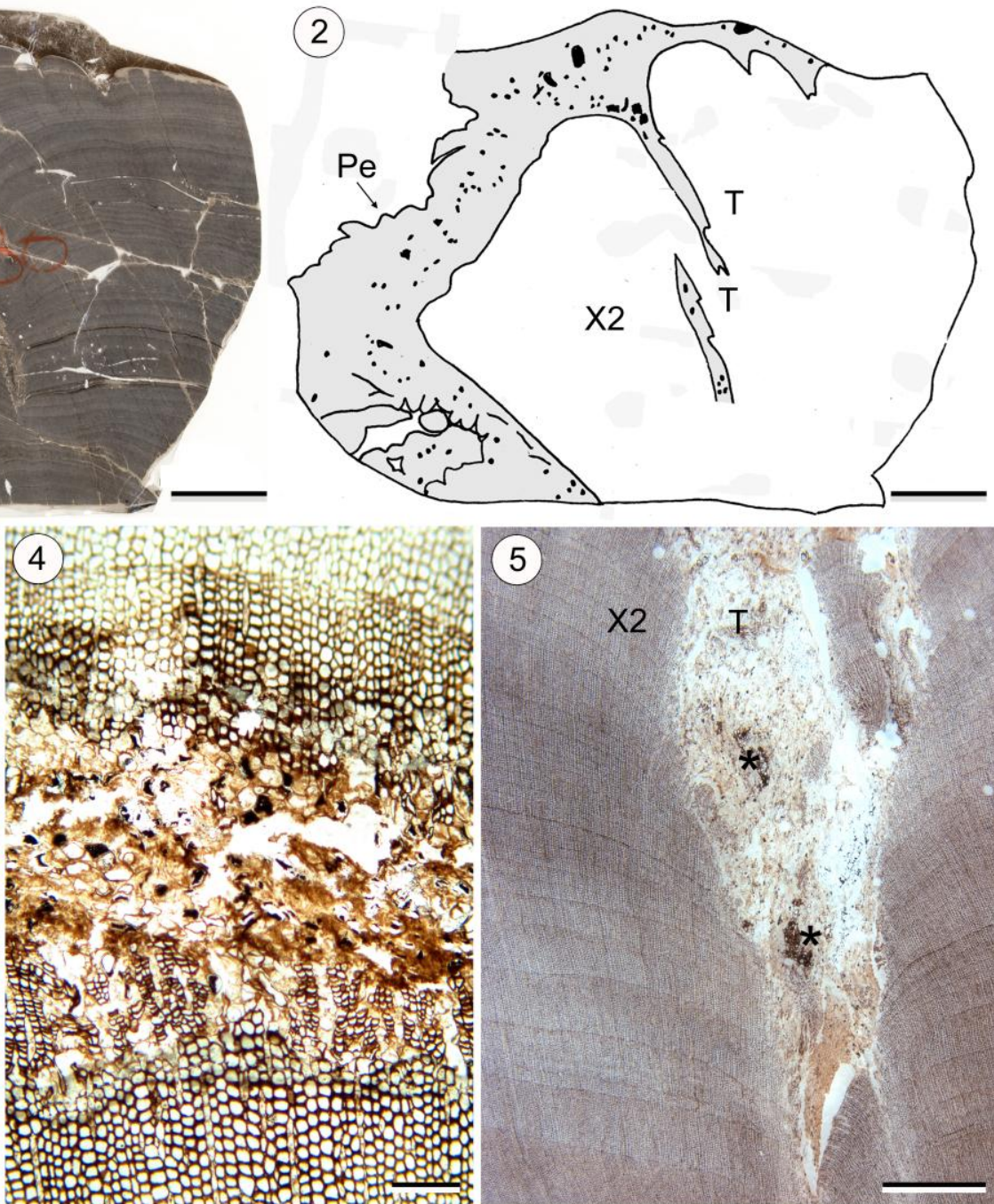

(5)
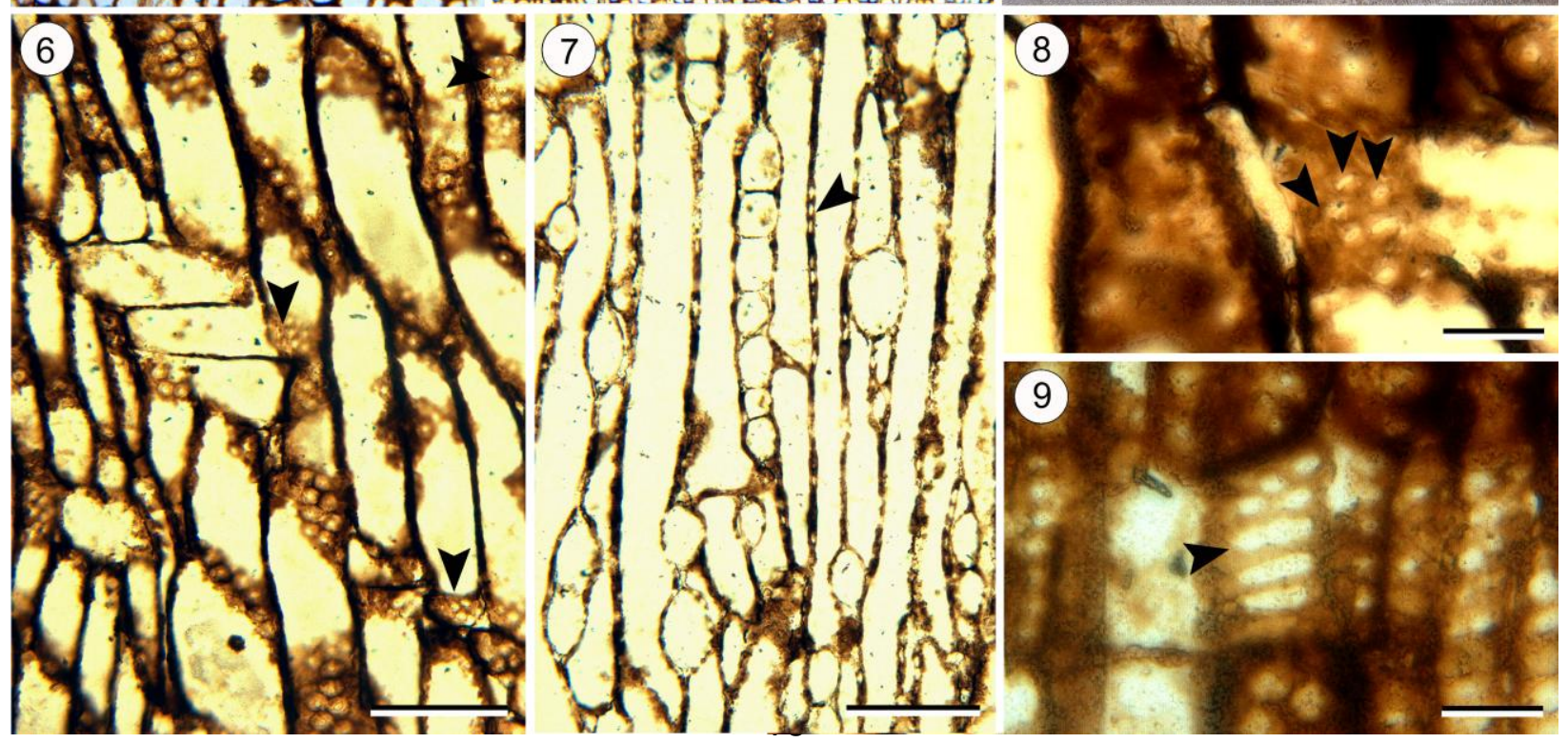
NOTICE: This is the author's version of a work accepted for publication by Elsevier. Changes resulting from the publishing process, including peer review, editing, corrections, structural formatting and other quality control mechanisms, may not be reflected in this document. Changes may have been made to this work since it was submitted for publication. A definitive version was subsequently published in Review of Palaeobotany and Palynology 163: 26-34, doi:10.1016/j.revpalbo.2010.09.002

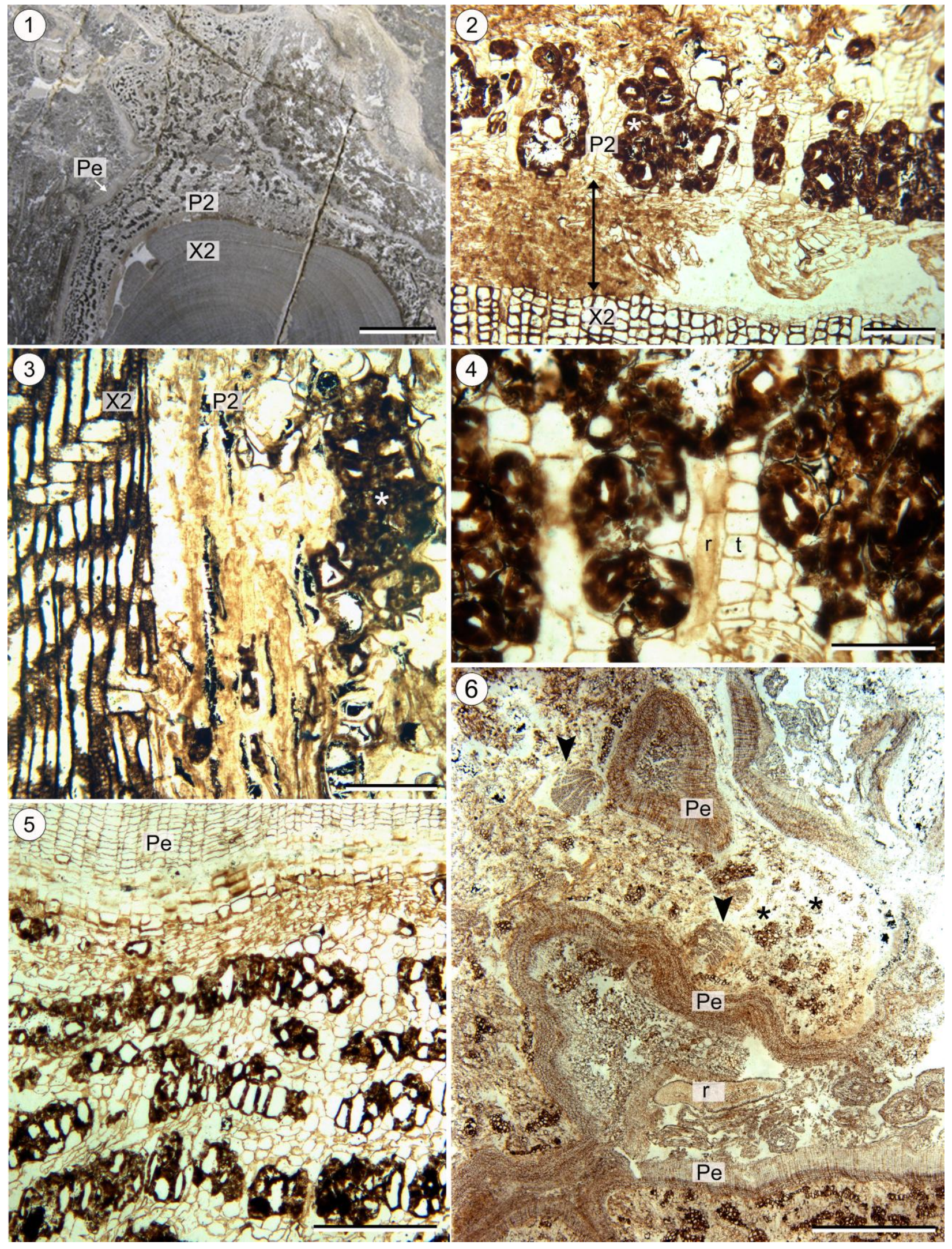


NOTICE: This is the author's version of a work accepted for publication by Elsevier. Changes resulting from the publishing process, including peer review, editing, corrections, structural formatting and other quality control mechanisms, may not be reflected in this document. Changes may have been made to this work since it was submitted for publication. A definitive version was subsequently published in Review of Palaeobotany and Palynology 163: 26-34, doi:10.1016/j.revpalbo.2010.09.002

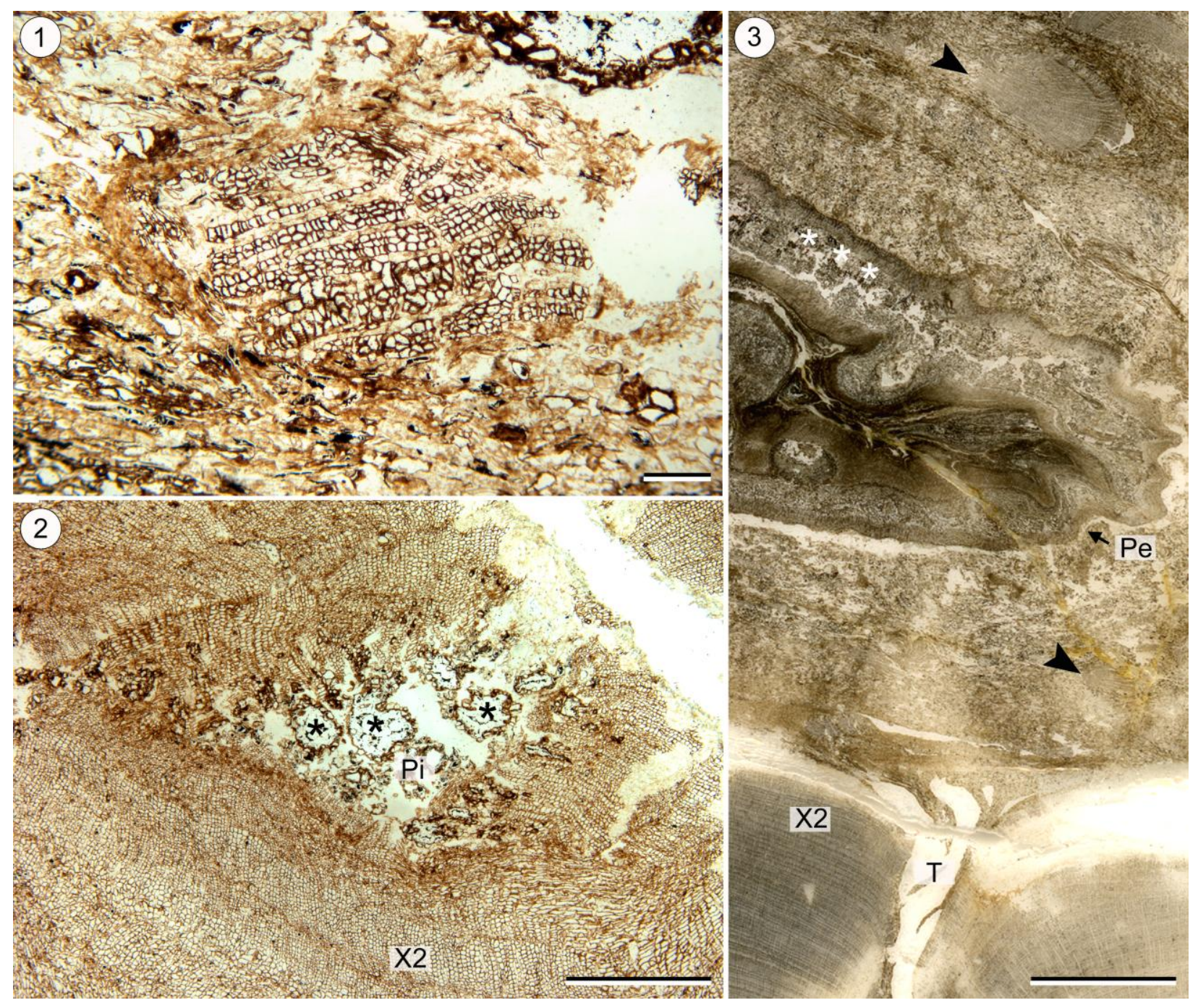

